$\xi=-1$

\title{
Organizational Cultures In Supporting SMEs Competitiveness Within Indonesian Silk Industry
}

\author{
Wahyuddin Latunreng ${ }^{1}$, Daryanto Hesti Wibowo ${ }^{2 *}$ \\ ${ }^{1,2}$ STIAMI Institute Of Management And Social Sciences \\ *Corresponding Author E-Mail: Wibowodar@Gmail.Com
}

\begin{abstract}
This study aims to determine the role of organizational culture in the context of the competitiveness of small and medium enterprises (SMEs) in the silk industry in Indonesia. The case studies carried out in Wajo, South Sulawesi as one of Indonesia's leading silk producer. The influence of organizational culture on competitiveness is analyzed quantitatively and qualitatively through field survey. Respondents came from silk businesses and local governments, Regent, Head of the Department of Trade and Industry. Then it is compared to the SMEs practices in several countries in Asia: Japan, China and India. The results showed that the organizational culture of SMEs silk in Wajo district classified as 'good' so that it is a strong capital in the development of silk industry in this area. Marketing, development of product design, advanced technology and copyright need attention in increasing competitiveness as a consequence of the free market. The results of this study support the Indonesian government that has recently turned out to specifically instruct Wajo local governments in taking strategic decisions to spur growth in this industry sector.
\end{abstract}

Keywords:

\section{Introduction}

Indonesia in the year 2010 was on the sixth position of natural silk producers below China, India, Brazil, Thailand and Japan (Table 1). High competition with producers in other countries, lack of government support for the industry and the obsolete technology as well as the handling of pests and diseases are thought to inhibit the development of cultivation and silkworm industry. This condition eventually has affected the silk weaving industry in Indonesia. Silkworms and cultivation techniques were introduced to Indonesia since the 10th century through trade between merchants China and Indonesia, originally developed in South Sulawesi. This is evident from the historical record that states Bugisnese terminology for silk such as sabek (silk), woena sabek and lipak sabek. Silk industry was then developed in South Sulawesi, one of which is Wajo, predominantly driven by households and SMEs.

Micro, small and medium enterprises (SMEs) in the national economy have important and strategic roles. The condition can be seen from various data that support the existence of SMEs that are dominant in the Indonesian economy. First, a large size of industry and it is found in every sector of the economy. Second, its great potential in employment, and the third, the contribution of SMEs to GDP is quite significant, amounting to $56 \%$ of total GDP in 2010.

The SME sector has proved resilient, when the economic crisis of 1998, only SMEs survived from the collapse of the economy, while the larger sector actually fell by the crisis. It is because of no foreign debt, less bank debt, the use of local inputs and exportorientation. During 1997-2006, the number of large-scale SMEs reaches $99 \%$ of all business units in Indonesia.

The important role of SMEs in the national economy is not only applicable in developing countries but also the developed countries. Japanese government has been aware of the important posi- tion of SMEs. The government paid special attention to the development of SME business segment. This is reflected in the 2014 white paper published by the Ministry of Economy, Trade and Industry of Japan who believe that SMEs are important in the Japanese economy in the future. Similarly, in China and India, the governments are active in supporting the advancement of SMEs through their policies. So the real support measures are in the form of policies on this business segment.

The previous study on the competitiveness of SMEs in the global economy showed that organizational culture plays an important role in determining the strategy of SMEs related to competitiveness. Furthermore, global competition threatens the majority of local SMEs whose sales are very local and much segmented. This situation could destabilize the sustainability of SMEs.

SMEs in Indonesia has been used as an instrument of social policy or policies to reduce unemployment or poverty. Thus SMEs are not seen as purely a business group. So that SMEs can be advanced and developing the business groups considered and if they are addressed as a purely business group. This means that SMEs can grow and develop to be entirely due to the creativity and innovation of entrepreneurs / owners, not because of being pushed or "forced" to live by various programs or credit schemes or special assistance from the government. The corporate culture based on innovation is what needs to be developed SMEs Indonesia to compete in an open global trade.

Corporate culture becomes a decisive factor of success or failure of companies in the next decade. Indecent corporate culture may cause negative financial impact because it can hinder the company in adopting the necessary changes strategically and tactically. Access to appropriate technology can be a major obstacle to the competitiveness of SMEs. In addition, excessive costs in product development as well as the ineffectiveness of the limited sales techniques and marketing research. It is called intellectual property management weaknesses as factors inhibiting competitiveness. 
From the above mentioned phenomenon, the problems faced by SMEs in silk industry can be identified as follows:

a. Cultural Organization on the management of the silk industry has not been recognized as an important asset in increasing competitiveness.

b. Entrepreneurs (SMEs) silk has not been well organized.

c. Marketing of silk products both domestically and abroad has not yet been well ordered.

d. Copyright concerns the creation motifs and designs have not been managed properly.

This study aims to determine the role of organizational culture in the context of the competitiveness of the SMEs in the silk industry in Indonesia. The case studies carried out in Wajo as one of Indonesia's leading silk producer. The research focused on organizational culture in the silk industry for generations as the capital to be competitive in an open market era. This study will answer the problems in the development of silk SMEs in organizing entrepreneurs, marketing, and copyright as a consequence of free competition.

The results of this study will help governments, particularly Wajo local government in taking strategic decisions to spur growth in this industry sector. At the end of this study will indicate that organizational culture plays an important role in improving the competitiveness of SMEs and a capital base in the face of the open market.

Table 1: Silk Production by Countries 2009 - 2010 (x100 ton)

\begin{tabular}{|l|l|l|l|l|}
\hline Countries & $\mathbf{2 0 0 7}$ & $\mathbf{2 0 0 8}$ & $\mathbf{2 0 0 9}$ & $\mathbf{2 0 1 0}$ \\
\hline China & & 986,20 & 840,00 & 1150,00 \\
\hline India & 183,20 & 183,70 & 196,90 & 204,10 \\
\hline Brazil & 12,20 & 11,37 & 8,11 & 7,70 \\
\hline Thailand & 7,60 & 11,00 & 6,65 & 6,65 \\
\hline Japan & 1,05 & 0,95 & 0,69 & 0,53 \\
\hline Indonesia & 0,65 & 0,37 & 0,19 & 0,20 \\
\hline Bulgaria & 0,08 & 0,08 & 0,06 & 0,10 \\
\hline
\end{tabular}

Source: International Sericultural Commission (2012)

\section{Literature Review}

\subsection{Organizational Culture}

Organizational culture is a pattern of basic assumptions shared and absorbed by a group to solve the problems associated with external adaptation and internal integration that has been running well enough to be considered as truth, therefore it is taught to new members as the correct way to understand, think and feel these issues. The organizational culture as shared values, principles, traditions and ways of doing things that affect the way members of the organization to act. Moreover the organizational culture is a unifying force that holds political conflict and promote mutual understanding, agreement on common procedures and practices.

In the process of helping to create a mutual understanding of organizational life, culture of the organization meet the four basic functions, namely: giving identity to the members of the organization, facilitating collective commitment, memdorong stability of the organization and shaping behavior by helping members understand their environment.

This research adopted the Organizational Culture Assessment Questionnaire (OCAQ). The identical concept is used on a survey of SMEs in the city of Hanno Japan in 2015. There are five dimensions of organizational culture, namely: Change Management, Goals, Coordination Teamwork, Customer Orientation and Cultural Strength.

Corporate culture becomes a decisive factor of success or failure of companies in the next decade. Good corporate culture is not a negative financial impact because it can hinder the company in adopting the changes necessary strategic and tactical.

\subsection{SME Competitiveness}

SMEs is regulated in Law No. 20 in 2008. According to the Act, in general, SMEs are hallmark traits: a stand-alone management, provided the capital itself, a local marketing area, the small company's assets, and a limited number of employees employed. The principle of the implementation of SMEs is togetherness, democratic economy, independence, balance of progress, sustainability and efficiency of justice, as well as national economic unity. Criteria for SMEs based on net assets and annual turnover is as follows:

SMEs in the national economy has an important and strategic role. The condition can be seen from various data that support the existence of SMEs that are dominant in the Indonesian economy. First, a large number of industry and found in every sector of the economy. Second, its great potential in employment, and the third, the contribution of SMEs to GDP is quite significant, amounting to $56 \%$ of total GDP in 2010.

Organizational culture plays an important role in determining the strategy of SMEs related to competitiveness. So that the power of organizational culture of silk in Wajo district SMEs have a capital base for the local government in drafting a strategy to revive the glory of the silk industry.

Furthermore, in a global competition, using current technology, the changing needs and demands of customers have shifted the paradigm of competitiveness. This change encourages organizations to compete in different dimensions such as developing new designs and products, adopting better production techniques, implementing market-oriented distribution, utilizing the latest communication technology and develop an effective marketing strategy.

Competitiveness is a productivity level of output produced by labor. The previous study on the competitiveness of SMEs in the global economy showed that organizational culture plays an important role in determining the strategy of SMEs related to competitiveness. Furthermore, in a global competition, using current technology, the changing needs and demands of customers have shifted the paradigm of competitiveness. This change encourages organizations to compete in different dimensions such as developing new designs and products, adopting better production techniques, implementing market-oriented distribution, utilizing the latest communication technology and develop an effective marketing strategy.

Table 2: SMEs Criteria in Indonesia

\begin{tabular}{|l|l|l|l|l|}
\hline No. & & $\begin{array}{l}\text { Micro } \\
\text { IDR }\end{array}$ & Small IDR & Medium IDR \\
\hline $\mathbf{1}$ & $\begin{array}{l}\text { Net asset excluded } \\
\text { land and building }\end{array}$ & $\begin{array}{l}\leq 50 \\
\text { mios }\end{array}$ & $\begin{array}{l}50 \quad-500 \\
\text { mios }\end{array}$ & $\begin{array}{l}500 \text { mios }-10 \\
\text { bios }\end{array}$ \\
\hline $\mathbf{2 .}$ & Annual Sales & $\leq 300$ & $\begin{array}{l}\text { IDR 300 } \\
\text { mios }-2,5 \\
\text { bios }\end{array}$ & $\begin{array}{l}\text { IDR 2,5 bios }- \\
50 \text { bios }\end{array}$ \\
\hline
\end{tabular}

Source: Indonesian Law No. 20/2008 Research Framework

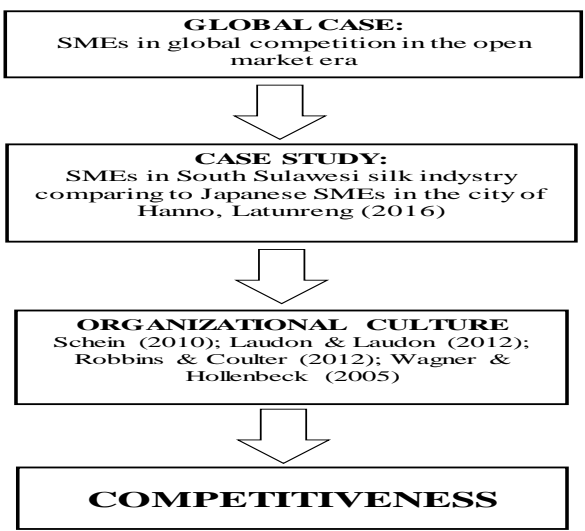




\section{Research Method}

The method used is descriptive method using survey. Survey methods used to obtain data from a particular place is as it is, but research taking action in collecting data, for example by circulating questionnaires, tests, interviews and so on. The survey was conducted to gather facts through questionnaires to the people intended as a source of information about the organizational culture in the context of competitiveness.

This research is an applied research and explorative using quantitative and qualitative methods (mix-method) with a case study of SMEs silk in Wajo.

The survey of SMEs conducted in the period of February-March 2017 was to determine the organizational culture in small and medium scale enterprises. Questionnaires and interviews were delivered to craftsperson, business people and the local government in the silk industry in Wajo regency, South Sulawesi. The survey questionnaire formulation of Organizational Culture Assessment Questionnaire (OCAQ). The identical method is used on a survey of SMEs in the city of Hanno Japan in 2015. Thirty questions in the likert-scale questionnaire representing the five dimen- sions of organizational culture, namely: Change Management, Goals, Coordination Teamwork, Customer Orientation and Cultural Strength.

Descriptive result from respondents can be used to enrich the discussion on each dimension and indicator variables of the study. To facilitate interpretation of the variables being studied, the respondents categorized based on the respondent rate.

Table 3. Respondents answer rate

\begin{tabular}{|c|c|c|}
\hline \multirow[t]{2}{*}{ Interval } & \multicolumn{2}{|c|}{ Categories } \\
\hline & Number & Percentage \\
\hline Max. Score & 5 & $100 \%$ \\
\hline Min. Score & 1 & $20 \%$ \\
\hline Levels & & \\
\hline $\begin{array}{ll}20,00 \% \\
35,99 \%\end{array}$ & \multicolumn{2}{|c|}{ Very Poor } \\
\hline $\begin{array}{l}36,00 \% \\
51,99 \%\end{array}$ & \multicolumn{2}{|c|}{ Poor } \\
\hline $\begin{array}{l}52,00 \% \\
67,99 \% \\
\end{array}$ & \multicolumn{2}{|c|}{ Fair } \\
\hline $\begin{array}{ll}68,00 \% \\
83,99 \%\end{array}$ & \multicolumn{2}{|c|}{ Good } \\
\hline $84,00 \%-100 \%$ & \multicolumn{2}{|c|}{ Excellent } \\
\hline
\end{tabular}

Table 4: Silk Capacity in Wajo Regency, 2009-2013

\begin{tabular}{|l|l|l|l|l|l|l|l|l|l|}
\hline $\mathbf{N o}$ & $\mathbf{Y}$ & Unit & Man & Investment & $\begin{array}{l}\text { Prod. Cap } \\
\text { (meter) }\end{array}$ & $\begin{array}{l}\text { Prod. } \\
\text { (IDR 000) }\end{array}$ & $\begin{array}{l}\text { Val } \\
\text { (Tot. Cap. }\end{array}$ & $\begin{array}{l}\text { Mat. } \\
\text { (IDR 000) }\end{array}$ & $\begin{array}{l}\text { Value } \\
\text { (IDR 000) }\end{array}$ \\
\hline $\mathbf{0 1}$ & $' 09$ & 5.235 & 15.705 & 9.432 .325 & 2.149 .550 & 112.851 .090 & 143.3 & 64.485 .000 & 48.366 .090 \\
\hline $\mathbf{0 2}$ & $' 10$ & 5.318 & 15.954 & 9.684 .125 & 2.149 .800 & 124.285 .150 & 143.3 & 64.485 .000 \\
\hline $\mathbf{0 3}$ & $' 11$ & 5.377 & 16.131 & 9.789 .525 & 2.150 .000 & 124.296 .879 & 143.3 & 71.650 .000 & 52.646 .879 \\
\hline $\mathbf{0 4}$ & $' 12$ & 5.377 & 16.131 & 8.789 .525 & 2.300 .000 & 139.500 .000 & 151.7 & 72.082 .000 & 67.418 .000 \\
\hline $\mathbf{0 5}$ & $' 13$ & 5.377 & 16.131 & 8.789 .525 & 2.300 .000 & 139.500 .000 & 151.7 & 72.082 .000 & 67.418 .000 \\
\hline
\end{tabular}

Source: Cooperatie and Industry Department, Wajo Regency

\section{Result and Discussions}

The survey of SMEs in the period of February-March 2017 was conducted to determine the organizational culture in small and medium scale enterprises. Questionnaires and interviews were delivered to craft persons, business people in the silk industry and the local government officers in Wajo regency, South Sulawesi.

Wajo became a center of natural silk fabric weaving industry Bugis. Weaving activities have been done for generations, both cultivating as a sideline activity and as industrial scale households and SMEs. Silk weaving businesses from upstream to downstream found on almost every sub-district in this area. Activities include natural Murbey crop planting, maintenance of silkworm (Bombyx mori, sp), until the silk yarn spinning, weaving silk fabrics, including silk origin product diversification development. Silk industrial production data in the district Wajo are presented in the following table.

The survey results in Table 2 show SMEs in Wajo district has an high organizational culture with an average score on the five dimensions are $81 \%$ classified as Good. Even the dimensions of customer orientation have the highest score, $87 \%$ (Very Good) and the lowest in Change Management with a score of $76 \%$ (Good). Descriptively, it can be said that silk SMEs in Wajo regency, South Sulawesi has strong organizational culture based on the guideline of respondent's rate in Table 3 .

Compared to the organizational culture of SMEs in the city of Hanno Japan on average is 'Fair', then the organizational culture of SMEs in Wajo district on average better classified as 'Good'. This is due to SMEs in Japan in general, still adhere to the family based governance. Conditions like this in Japan is actually not only applies to SMEs but also to large enterprises, multinational though. For example, Toyota management until now is still held by the Toyoda family dynasty. Nonetheless, no one deny that Toyota has high competitiveness, it is evident to this day the brand is the leader of the world automotive market.
The previous study on the competitiveness of SMEs in the global economy showed that organizational culture plays an important role in determining the strategy of SMEs related to competitiveness. So that the power of organizational culture of silk in Wajo district SMEs have a capital base for the local government in drafting a strategy to revive the glory of the silk industry.

Furthermore, in a global competition, using current technology, the changing needs and demands of customers have shifted the paradigm of competitiveness. This change encourages organizations to compete in different dimensions such as developing new designs and products, adopting better production techniques, implementing market-oriented distribution, utilizing the latest communication technology and develop an effective marketing strategy.

The main constraints faced by SMEs is access to technology, in addition to the high cost of new product development, as well as the ineffectiveness of the limited sales techniques and market research

From interviews with silk business people and local governments, Regent, head of the Department of Trade and Industry. The results showed that the organizational culture of SMEs silk Wajo district classified as 'good' so that a strong capital in the development of silk industry in this area. Marketing, development of product design, advanced technology and copyright need attentions in increasing competitiveness as a consequence of the free market. The problems faced by SMEs are in accordance with the matters presented in previous studies mentioned above.

To overcome this problem, in India, the government has formed a special bank handles small industry for the development of technology and modernization, thus spurring an increase in the quality of production in accordance with market needs. Besides, the government also assist SMEs by organizing product marketing international exhibitions and finance delegation to participate in meetings open product marketing opportunities. All these efforts are supported by government policies that support the development of SMEs.

Meanwhile in China, the government's policy focus is to improve the operational environment of SMEs through Chinese SMEs 
Promotion Law in 2003. With the publication of the policy position of SMEs to be clear and the responsibility of the relevant ministries. The law states that the government is actively supporting SMEs, with financial and taxation policies to improve the quality of SMEs to become competitive.

Similar to the Chinese government, the Japanese government paid special attention to the development of MSME business segment. This is reflected in the 2014 white paper published by the Ministry of Economy, Trade and Industry of Japan who believe in the important role of SMEs in the Japanese economy in the future. So the real support measures in the form of a policy on this business segment will soon be realized.

Based on the above research, the strategy of SMEs in silk industry to win the global competition must be based on the organization's culture, proved stronger in SMEs silk. Later, reflecting on the development strategy of SMEs in India, China and Japan, the government's policy support is needed to sharpen the competitiveness of products through the silk trade governance including copyright issues, development and marketing of products. Hence the need for cooperation between the central government and local governments following related agencies.

Table 5: Total Respondent Answers SMEs Wajo, South Sulawesi

\begin{tabular}{|l|l|l|l|}
\hline No. & Dimensions & Rate & Category \\
\hline 1. & Change Management & $75,76 \%$ & Good \\
\hline 2. & Goal Achievement & $83,33 \%$ & Good \\
\hline 3. & Teamwork Coordination & $81,82 \%$ & Good \\
\hline 4. & Customer Orientation & $86,67 \%$ & Very Good \\
\hline 5. & Cultural Strength & $78,18 \%$ & Good \\
\hline
\end{tabular}

Source: Latunreng (2016)

\section{Conclusion}

Based on the research in Wajo, South Sulawesi as one of the silk weaving base in Indonesia, the researchers concluded that the necessary government support through policies to improve the competitiveness of SMEs silk primarily on the following matters: Cultural Organization on the management of the silk industry has not been recognized as an important asset in increasing competitiveness. Although this research proves that the organizational culture of businesses in the silk industry quite well.

Entrepreneurs (SMEs) silk was not well organized so that required their governance policies silk trade.

Marketing of silk products both domestically and abroad not well ordered, so that the necessary coordination in efforts to market the products of silk.

Copyright concerns the creation motifs and designs have not been managed properly. It is associated with certainty on the development of product designs that will bring new designs which are more contemporary that fit to the demands

\section{References}

[1] Creswell, J. W. 2009. Research Design: Qualitative, Quantitative and Mixed Methods Approaches. Thousand Oaks, CA: SAGE Publications, Inc.

[2] Gunasekaran, A., Marri, H.B., Mcgauahey, R. and Grieve, R.J. 2001. Implications of organization and human behavior on the implementation of CIM in SMEs: an empirical analysis. International Journal of CIM, Vol. 14 No. 2, pp. 175-85.

[3] Hashim, M.K. and Wafa, S.A. 2002. Small and Medium Sized Enterprises in Malaysia-Development Issues. Prentice-Hall, Englewood Cliffs, NJ.

[4] Kotler, Phillips. 1992. Marketing Management. Public Union.

[5] Latunreng, Wahyuddin. 2016. Budaya Organisasi.

[6] Laudon, Kenneth C. \& Laudon, Jane P. 2012. Management Information System - Managing The Digital Firm, 12th ed. Pearson Prentice Hall.

[7] Liker, Jeffrey K. 2004. The Toyota Way: 14 Management Principles from the World's Greatest Manufacturer. McGraw-Hill.
[8] Ministry of Economy, Trade and Industry of Japan. 2014. White Paper on Small and Medium Enterprises in Japan.

[9] Robbins, Stephen P. \& Coulter, Mary. 2012. Management, 11th ed. New Jersey: Prentice Hall.

[10]Rothfeder, Jeffrey. 2014. Driving Honda: Inside The World's Most Innovative Car Company. Brilliance Audio.

[11] Sashkin, Marshall and Rosenbach, William E. 2013. Organizational Culture Assessment Questionnaire.

[12] Schein, E. H. 2010. Organizational Culture and Leadership, 4th ed. San Fransisco: John Wiley \& Son.

[13] Sekaran, U. 2003. Research Methods for Business: A Skill-Building Approach, 4th ed. New York: John Wiley \& Sons, Inc.

[14] Shi, J. and Li, P. 2006. An initial review of Policies for SMEs in the US, Japan and China. IEEE International Conference on Management of Innovation and Technology, pp. 270-4.

[15] Singh, R.K., Garg, S.K. and Deshmukh, S.G. 2010. The Competitiveness of SMEs in Global Economy. Management Research Review, Vol 33. No. 1. Emerald Publishing Limited.

[16] Sugiyono. 2011. Metode Penelitian Bisnis Kombinasi. Bandung: CV Alfabeta.

[17] Tambunan, T. 2008. Ukuran Daya Saing Koperasi dan UKM. Jurnal Pusat Studi Industri dan UKM.

[18] Wagner III, John A. \& Hollenbeck, John R. 2005. Organizational Behavior: Securing (Atmosoedarjo, 2000)Competitive Advantage, 5th ed. New York: Routle

[19] Author,"Title of the Paper", Journal name, Vol.X, No.X, (200X), pp.XX-XX, available online: http://xxx, last visit:28.02.2013

[20] Author,"Title of the Paper", Proceedings of the conference name, Vol.X, No.X, (200X), pp:XX-YY, http://dx.doi.org/10.1109/MMM.2013.2248651

[21] Author, Title of the Book, Publisher, (200X), pp:XXX-YYY.

[22] Cho JH, Chang SA, Kwon HS, Choi YH, KoSH, Moon SD, Yoo SJ, Song KH, Son HS, Kim HS, Lee WC, Cha BY, Son HY \& Yoon $\mathrm{KH}$ (2006), Long-term effect of the internet-based glucose monitoring system on HbA1c Reduction and glucose stability: a 30-month follow-up study for diabetes management with a ubiquitous medical care system. Diabetes Care 29, 2625-2631.

[23] Fauci AS, Braunwald E, Kasper DL \& Hauser SL (2008), Principles of Harrison's Internal Medicine, Vol. 9, 17thedn. McGraw-Hill, New York, NY, pp.2275-2304.

[24] Kim HS \& Jeong HS (2007), A nurse short message service by cellular phone in type- 2 diabetic patients for six months. Journal of Clinical Nursing 16, 1082-1087.

[25]Lee JR, Kim SA, Yoo JW \& Kang YK (2007), The present status of diabetes education and the role recognition as a diabetes educator of nurses in korea. Diabetes Research and Clinical Practice 77, 199204.

[26] McMahon GT, Gomes HE, Hohne SH, Hu TM, Levine BA \& Conlin PR (2005), Web-based care management in patients with poorly controlled diabetes. Diabetes Care 28, 1624-1629.

[27] Thakurdesai PA, Kole PL \& Pareek RP (2004), Evaluation of the quality and contents of diabetes mellitus patient education on Internet. Patient Education and Counseling 53, 309-313. 